\title{
Mysterious boring hidden within the hinge plates of heterodont bivalves
}

\author{
JORDI MARTINELL, ROSA DOMÈNECH \& RICHARD G. BROMLEY
}

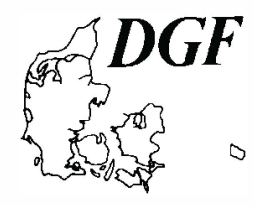
Martinell, J., Domènech, R. \& Bromley, R. G.: Mysterious boring hidden within
the hinge plates of heterodont bivalves. Bulletin of the Geological Society of
Denmark, Vol. 45, pp. 161-163. Copenhagen 1999-01-30.
https://doi.org/10.37570/bgsd-1998-45-21

Well-hidden beneath the umbo of heterodont bivalves, a sack-like boring is etched into the two hinge plates of the opposed valves. The boring is abundant, occurs in numerous host species, ranges from Eocene to today and appears to have world-wide occurrence. The trace fossil is named Umbichnus inopinatus nov. igen. et isp. The nature of the tracemaker remains unknown. The possibility that the struc-ture is a dissolution pit produced by the bivalve itself is discussed.

Key words: Boring, umbo, burrowing bivalves, Umbichnus inopinatus.

J. Martinell \& R. Domènech, Departament de Geologia dinàmica, Geofísica $i$ Paleontologia, Facultat de Geologia. Universitat de Barcelona, E-08071 Barcelona, Spain. R. G. Bromley; Geologisk Institut, Øster Voldgade 10, 1350 Copenhagen K, Denmark. 17 July 1998.

A common boring occurs in an unusual but constant position in the shells of bivalves. The boring is sackshaped, and is emplaced in and between the opposed hinge plates of the two valves of the shell, just beneath the umbo and dorsal to the hinge teeth. The boring has been observed by many bivalve workers in the past, but not all identified the structure as a boring. In fact, excellent descriptions and illustrations have been published (e.g., Dollfus et al., 1904), but some authors have assumed the structure to be an integral part of the anatomy of the shell (e.g., Stchepinsky, 1938).

The host bivalve is invariably a heterodont, and a large number of host species have been identified. Study of museum collections (particularly the Museum of Natural History, Paris and the Department of Dynamic Geology, University of Barcelona), as well as published illustrations, has so far revealed the boring in about 31 species. These are distributed among the Carditidae, Arctidae and Veneridae, from Eocene to Recent. The boring today appears to have world-wide distribution, whereas in the geological record it has been reported from the Mediterranean area and northern Europe.

The size of the boring varies considerably, both within the same species of host, and according to the size of the host species. In large hosts, such as Pelecyora islandicoides (Fig. 1) the boring may reach a length of almost $2 \mathrm{~cm}$. In large specimens, the dorsal part of the boring encroaches on the external ligament, causing it some erosion. The ligament comes to pro- vide a roof over the cavity. Ventrally, large borings may also encroach somewhat into the cardinal hinge teeth, but this is unusual. No example has been seen that was so large as to have threatened the functions of ligament or hinge. Thus, the presence of the borer does not seem to have been to the detriment of its host.

\section{The boring}

The boring occupies both valves of the host shell (Fig. 2 ). There is no bored aperture; the natural slit beneath the curl of the umbo seems to admit access to the protected space above the hinge. In this space, the borer has dissolved aragonite to enlarge its abode. Toward the cardinal teeth it leaves a thin plate of shell material. In other directions it expands irregularly: a little dorsally, more so laterally, but chiefly in the direction of the bivalve's posterior. This produces an irregular sack-shaped cavity that cuts slightly into the ligament at its anterior end.

\section{The tracemaker}

The flattened cavity, crossing between the two valves, and having a very narrow, slit-like opening to the exterior, suggests the work of a worm-like animal. Per- 


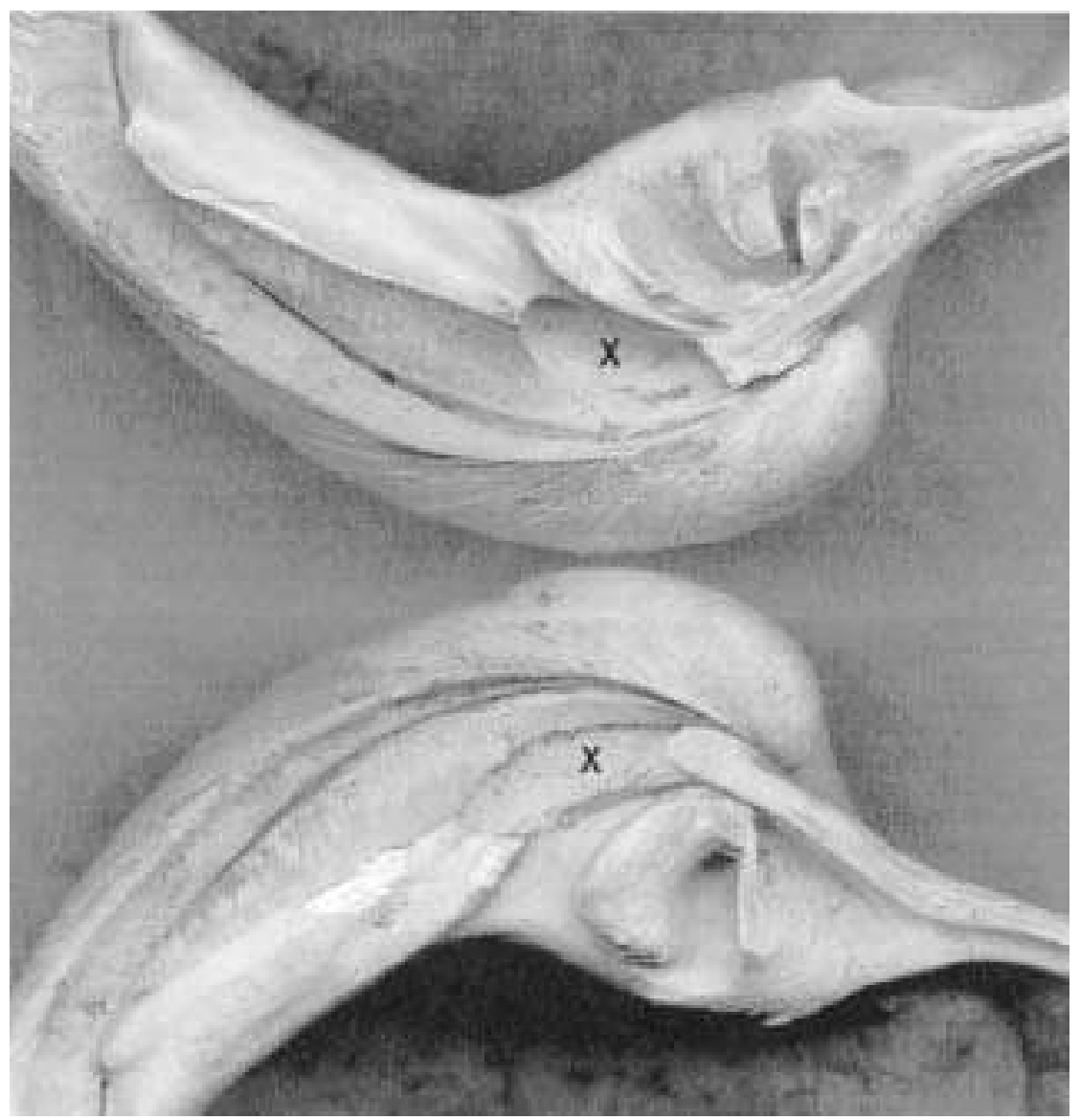

Fig. 1. Scanned computerized image of the holotype of Umbichnus inopinatus $(\mathrm{X}, \mathrm{X})$ beneath the umbones of the host bivalve, Pelecyora islandicoides. Slightly enlarged.

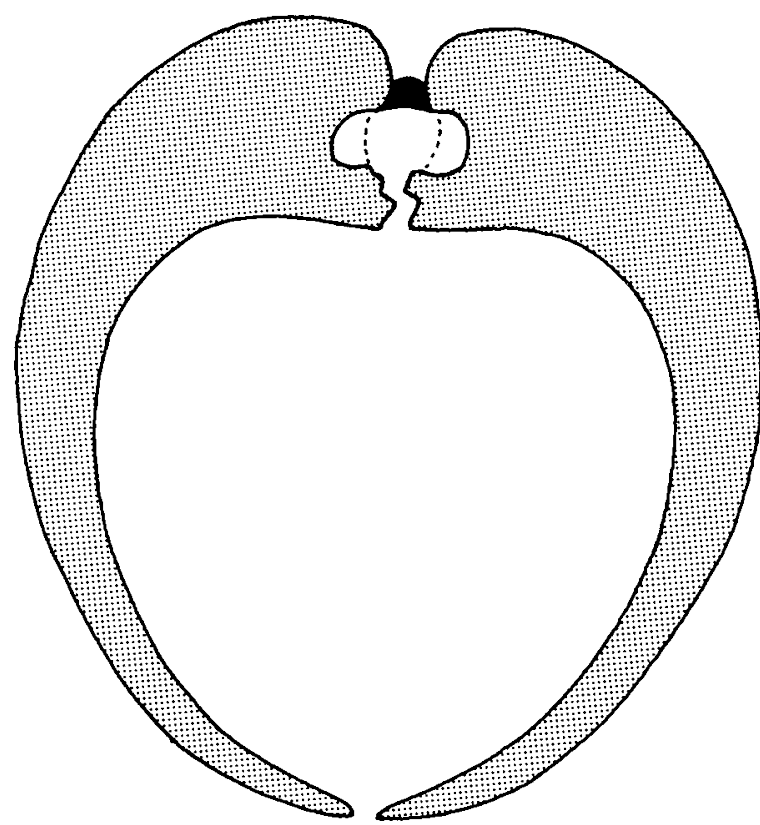

Fig. 2. Sketch of a cross section across the umbonal region of a heterodont bivalve, showing the boring etched into the hinge plates. Broken line, the pre-boring profile. The ligament is shown in black. haps a sipunculan could pass a slender introvert through the slit, or a bonellid echiuran a flattened proboscis. Likewise, a terebellid polychaete could spread a fan of tentacles out from this aperture. So far, dried, recent material has not revealed the nature of the borer, but owing to its abundance this should not be difficult to discover.

The large majority of heterodont bivalves are burrowers in sandy or muddy sediment. The location of the borer within the shell would place it at the distal extremity of the bivalve's burrow (Fig. 3). Perhaps organic material would be available at this site to support the life processes of the isolated animal, although the dissemination of genital products might not seem so easy.

\section{The trace fossil}

The trace fossil is distinctive and clearly defined. We therefore provide it with a name in order to stimulate further study of it and its producer. 


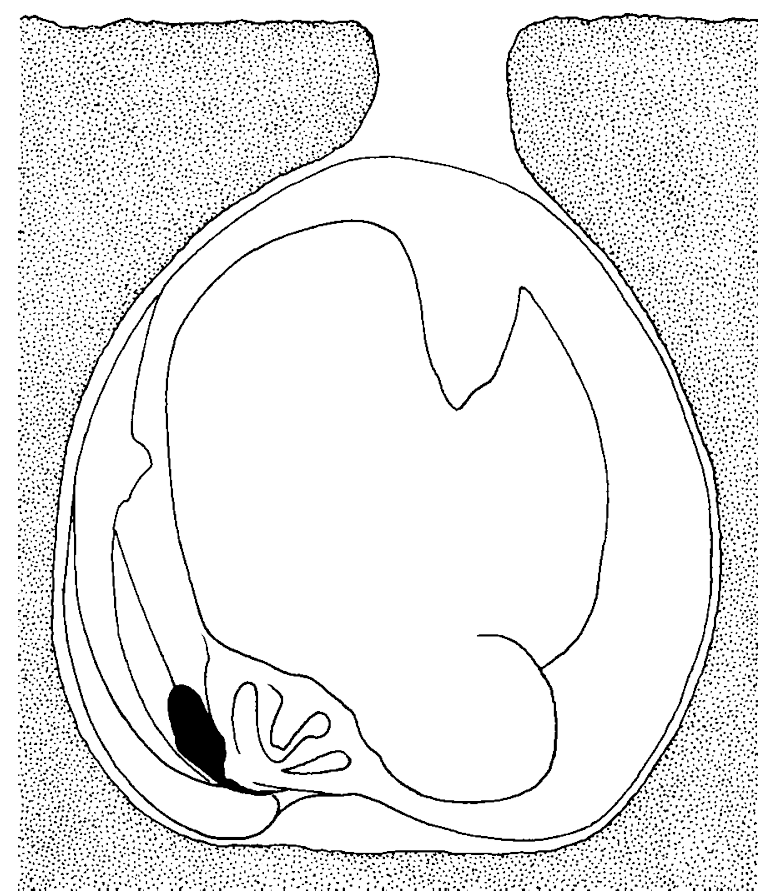

Fig. 3. Sketch showing the bivalve Pelecyora islandicoides in position within its burrow. The location of the boring is indicated in black.

Ichnogenus Umbichnus nov. (Fig. 1)

Type ichnospecies by monotypy: Umbichnus inopinatus nov.

Holotype: MGUH 24886, housed in the Geological Museum, Copenhagen. Host shell, Pelecyora islandicoides.

Locus typicus and stratum typicum: Lucena del Puerto (Hvelva, Spain, map reference x:6 $43^{\prime} 13^{\prime \prime}$, y: $37^{\circ} 17^{\prime}$ $\left.59^{\prime \prime}\right)$. Zanclean, Lower Pliocene.

Diagnosis: Sack-shaped boring having a single aperture, etched into both valves of bivalves in the hinge plates beneath the umbones.

Remarks: Savazzi (1995) described cavity formation causing deformation of the hinge area in Isognomon maxillatus (Pliocene), interpreted as the work of parasites. However, this has little morphological similarity with Umbichnus inopinatus.

\section{Alternative interpretation}

The mode of formation of the cavity might be interpreted as an autodissolution process caused by the bivalve itself. This might explain the wide distribution of the structure both geographically and through host taxonomy. However, the reason for dissolution at that site remains obscure. The presence of the cavity does not appear to improve the opening ability of the valves, whereas it does possibly pose a threat to the functioning and strength of the ligament. Neither does autodissolution explain the existence, in species that commonly display the cavity, of abundant adult specimens of that do not show the cavity.

We prefer to consider the structure a trace fossil produced by another animal, but the question cannot be resolved at present.

\section{Dansk sammendrag}

En sækformet boring findes ofte hos heterodonte muslinger. Boringen er skjult under umbonerne og påvirker begge skallers hængselregion. Boringen findes hos mange slægter fra eocæn og til nu og synes at være af global udbredelse. Sporfossilet er her beskrevet som Umbichnus inopinatus nov. igen. et isp. Spordanneren er stadig uidentificeret. Den mulighed at strukturen er et opløsningsfænomen skabt af muslingen selv diskuteres.

\section{References}

Dollfus, G. F., Berkeley Cotter, J. C. \& Gomes, J. P. 1904 : Mollusques tertiaires du Portugal. Commission du Service Géologique du Portugal, Lisbonne.

Savazzi, E. 1995: Parasite-induced teratologies in the Pliocene bivalve Isognomon maxillatus. Palaeogeography, Palaeoclimatology, Palaeoecology 116, 131-139.

Stchepinsky, V. 1938: Contribution à l'étude du Sahelien de Tunisie. Memoires de la Société Géologique de France, N. S. 16 (2-3), 1-121. 